\title{
Marxism and Psychology: An Outdated Interest or a Promising Research Field?
}

\section{Gezgin UB*}

Duy Tan University, Vietnam

*Coressponding author: Dr. Ulaş Başar Gezgin, Duy Tan University, 03 Quang Trung

Street, Danang, Vietnam, Tel: +84908374072; Email: ulasbasar@gmail.com

\section{Review Article}

Volume 3 Issue 6

Received Date: June 29, 2018

Published Date: July 13, 2018

\section{Abstract}

In this article, 'Marxist psychology' is introduced within a historical and theoretical context. 'Which Marxism?' and 'which psychology?' were the initial questions for discussion which brought responses related to historical personalities, movements, schools of thoughts, countries and subfields. Alienation, ideology and methodology were considered to be major themes for a Marxist psychology. The relationship between Marxism in power (e.g. Marxism(s) in former Soviet Union and the People's Republic of China) and psychology was considered as a separate category to compare and contrast it with Marxist criticisms aimed at capitalism in capitalist countries. After briefly discussing the links between Marxism and critical psychology, the article proceeds to subfields of psychology to discuss the actual and potential links.

Keywords: Marxism; Marxist psychology; Critical psychology; Marxist social psychology; Marxist industrial psychology

\section{Introduction}

For a discussion on Marxism and psychology, the first questions to ask are "which Marxism?" and "which psychology?" At a country level, we will have intersections such as Cuban Marxism and psychology, Chinese Marxism and psychology etc. At a personal level, the connections can be sought for Lenin and Freud; Mao and Jung etc [1]. These personal comparisons can be enhanced by a focus on various relevant themes. For example, a discussion about violence and aggressiveness according to Lenin and Freud would provide an opportunity to compare and contrast a Leninist approach that proposes that imperialism is the source of the world wars and a Freudian approach whereby aggressiveness is considered to be a major component of human nature manifesting itself not only in war but also in symbolically aggressive acts such as sports [2].
At a movement or schools of thought level, we can consider Marxism and Gestalt psychology, Marxism and behaviorist psychology etc. Furthermore, another comparison and contrasting could be made between Marxism and subfields of psychology such as political psychology, forensic psychology, industrial psychology, social psychology etc. but not all of the subfields of psychology could be equally relevant for discussions of Marxism. Another line could be drawn between Marxism(s) in power and Marxism(s) in opposition as stated above. As very well known, Marxism for a number of decades was the official ideology of the former socialist countries which had different conceptualizations of an institutionalized version of psychology. Contrary to this situation, when Marxism was in opposition rather than in power, it was more critical and expected psychology to be critical as well. 


\section{Psychology \& Psychological Research International Journal}

Elhammoumi (2012) briefly defines Marxist psychology as "the study of the social individual within social relations of production" (p.3) [3]. Elsewhere, Elhammoumi (2002) states that "the hostility of mainstream psychology toward Marxism has contributed to the widespread ignorance of the contributions of Marx's writings to the development of the human mind" (p.98) [4]. Marx did not specifically thought and produced works about psychology, however he elaborated on a number of psychological themes [5]. The first ones that come to mind are the notions of false consciousness and alienation. Hayes (2015) assigns 2 tasks to Marxist psychology: "to study (and criticise) the effects of life under capitalism for ordinary people" (p.21) and "to identify and imagine alternative societal and collective arrangements that would make our lives less miserable, less alienating (...)" (p.21) [6].

In an earlier work, Hayes (2001) states that "[i]n a substantive sense there isn't very much to say with regard to Marxism and psychology, as Marxism has been so absent from the theory and practice of Psychology. Psychology has insulated itself from social theory, in general, and in the particular case of Marxism, has been quite hostile to this "inappropriate" and "political" body of thought [7]."

Alienation, ideology and methodology were the major themes of the 1st Marxism and psychology conference which was held in 2010 at Prince Edwards Islands [8-11]. Ideology discussions included the notion of false consciousness, while methodology discussions revolved on what would be the characterizing properties of Marxist psychological methodologies [11].

Sica (1980) claims that "[h]ope for a plausible "MarxFreud synthesis" was engendered in social science long ago through Reich's work, then transformed and enlarged somewhat later by Marcuse [12]." (p.971) Guido (2015) identifies a number of similarities between psychoanalysis and Marxism in terms of their objectives, means, method, dialectics, interpretation of history and models. Although Marxism and psychoanalysis were intertwined by a number of writers such as Lacan, Fromm, Reich and Fanon, Marxism and psychology are rarely studied as a whole. Since psychology can't be equated with psychoanalysis, works by Lacan and others are not necessarily applicable for the current field of psychology [13].

Let us also note that psychology is not only a research field, but a practice. It is a helping profession rather than a field of academic research only. Most of the psychologists over the globe are not academic researchers, which means that the practicality of a discussion of Marxism and psychology on the basis of what psychology professionals do is more than justified. Class positions of psychologists could be a viable starting point [14]. Although it is considered to be a middle class profession considering the income that can be earned by working as a psychologist, increasing number of psychology graduates leads to precarization and proleterianization of psychologists together with the destructive effects of neoliberal policies. In this vein, another question is the following: How can and do Marxist-oriented practitioners of the profession of psychology differ from others? Are practicing psychologists to be considered as guardians of status quo and to be rebelled against or is there anything to salvage in this helping profession? These are major questions for a Marxist psychology practice $[15,16]$.

Another distinction to be made is about using Marxism for critical interpretation vs. for social change [17]. Hayes (2001) finds discussions of Marxism and psychology useful as they would be conducive to identify the likely contributions of Marxism to critical psychology and distinguishes a theoretical approach to Marxism and psychology, and a historical approach which focuses on how both notions interacted with each other through the recent history [7]. In that sense, in the next section we will be briefly presenting and discussing Marxist psychology in the Soviet Union and People's Republic of China.

\section{Marxism in Power and Psychology}

For the relationship between Marxism in power and psychology, we have to investigate the works of Soviet researchers such as "Pavlov, Bekhterev, Bernstein, Uznadze, Luria, Vygotsky and Blonsky", Rubinstein, Leont'ev (Thielen, 1986, p.114) and Zaporozhets, Basov and Ananiev $[18,19]$. However, since our main focus in this article is not Soviet psychology, we will only have brief comments about the overall character of the Soviet psychology.

Unlike the attempts at marrying Marxism and psychoanalysis elsewhere, Freudian theory was ridiculed and finally left without any financial support in the Soviet Union [20]. Psychoanalysis was considered to be a bourgeois movement urging the people to look inward to solve social problems rather than outward. While Freud epitomized idealism, Pavlov offered a materialist scientific approach to human beings according to the Soviet official discourse. Brenner (1997) finds it surprising to see that Pavlov's physiological reductionism 


\section{Psychology \& Psychological Research International Journal}

was positively received by the Soviet Marxists with Pavlov's socially disconnected view of human beings, a form of behaviorism [21]. Thus Marxism in power in the case of the Soviet Union was in favor of a form of behaviorism against the introspective-based approaches that were deemed non-scientific [22-25]. Besides reductionism, Soviet psychology was criticized as it relied on an official, dogmatic version of Marxism [26].

Payne (1967) identifies 3 different aspects of the brain-psyche problem' in Soviet psychology which has a number of parallels in the mind-body problem of the field of philosophy of mind: "(a) the epistemological aspect, i.e. the relationship of consciousness to the external world; (b) the social aspect, that of its relation to society; (c) the natural-science aspect, i.e. the problem of the relationship of consciousness to the brain" (p.83) [27]. These three aspects had repercussions in other research areas of psychology. How to study psychology with a materialistic perspective but also in a way to recognize social forces over the make-up of psychology and interactions was a major theoretical riddle for Soviet psychology with implications for psychology practice as well.

It was ironic to see that in Soviet Union where social relations were emphasized in both social science and official discourse, the field of social psychology did not develop much [28]. While Western psychology started with the individual and complemented itself by the study of group processes through social psychology, Soviet psychology started with the social relations of an individual and continued as such, rarely considering the influence of group processes over human psychology.

On the other hand, personality research that classifies Soviet workers on the basis of attitudes towards work (Rahmani, 1973) is notable Not all are equally motivated. Whether Soviet workers were alienated or not (Rahmani, 1973) is an interesting point of discussion. They are motivated by "public value of work", "work collective", "creative initiative", "possibility of professional advance", "organization of work", "independence in work" and "good wage" [28]. As the heterogeneity of these motivation types show, some workers were more motivated by financial benefits while others were more ideologically motivated. Yet another group of workers were motivated by creativity or career prospects [28].

The shining star of the Soviet psychology was Vygotsky. He has been the most widespreadly known Soviet psychologist in the Western world. Veresov (2005) is in the opinion that Vygotsky's psychology had Marxist elements (such as the notion of "the social origins of mind") as well as non-Marxist elements (such as not endorsing "the role of human activity (practice) in mental development" in the way other Soviet psychologists did) (p.37, p.42) [29]. Contrary to this characterization, Packer (2008) argued that Vygotsky's psychology was a Marxist one and Marxist psychology was an objective psychology according to him [30,31]. Marxism was viewed by Vygotsky as the solution for the crisis of psychology [32]. According to Edwards \& Daniels (2004) "[h]is mission was to create a Marxist psychology, as a science which could explain how mind and world interacted and how they were both transformed by these interactions. His concerns were both cognitive and social and he worked within a field of applied psychology which was primarily concerned with learning and how it might be supported" [33].

For People's Republic of China, the period between the foundation (1949) to the end of the Cultural Revolution (1976) is considered to be characterized by Marxist psychology studies influenced by Soviet psychologists and Marxist influences over Chinese psychology is still dominant according to Yang \& Ye (2013) [34,35]. For Chinese Marxist psychology, Shu Pan (1897-1988) is considered to be one of the leading figures [36]. Shu Pan was the president of Chinese Psychological Society for 3 decades. His biography shows us that psychology was an active research area in Mao's tenure, while the Cultural Revolution hindered development of psychology, as psychology was denounced as a pseudoscience and were repressed. For him, psychology had to help the socialist construction and development. Rather than copying Western psychology he was in favor of developing a psychology with Chinese characteristics [36].

According to Teo (1999) "[f]or many psychologists who seek to incorporate Marxist thinking into their domain, this relationship is ambivalent. Marxism offers an uncorrupted intellectual framework, but is discredited due to real experiences in socialist countries and its failure as a state doctrine in former Eastern European countries, China and other nations" (p.428) [37].

Although Teo (1999) might be right about unscientific ideological debates about Marxism and psychology in countries where Marxism was in power, the situation is getting quite different with the new course of political and economic events in the world. Due to the crisis of capitalism especially by 2008, a growing number of researchers disagree about ultimate victory of capitalism and defeat of socialism. The Soviet experiences have been carefully studied to draw lessons for the future. The 


\section{Psychology \& Psychological Research International Journal}

failure is attributed to a version of socialism, rather than socialism as a whole. Thus Teo (1999)'s views about the subject may no longer be applicable. It just reflects the shock and surprise of an unexpected collapse of the Soviet Union a couple of years before [37].

\section{Marxism and Critical Psychology}

Another point to discuss following the relationship between Marxism in power and psychology would be the relationship between Marxism and critical psychology. Barnes \& Milovanovic (2015) criticizes mainstream psychology as class positions and class consciousness are psychologized and stripped off of the structural determinants of the classes, while Prilleltensky (1990) criticizes the mainstream 'abnormal' psychology due to its asocial and a historical understanding of the individual as well as attributing psychological problems to a person's deficiencies rather powerful social determinants such as poverty, unemployment etc $[38,39]$. On the other hand, let us note that not all criticisms of the mainstream can be considered as Marxist psychology, as the term critical psychology would also include diverse approaches and areas such as Black psychology, feminist psychology, gay psychology etc [40]. However, as Holzman (2013) elaborately puts it, some of the criticisms can quickly become a part of the mainstream. Nevertheless, Holzman (2013) classifies criticisms of mainstream psychology into three categories noting their overlaps: The identity-based, ideology-based and epistemology-based criticisms [40].

The identity-based positions criticize WASP (White Anglo-Saxon Protestant) character of the mainstream psychology questioning the universality claimed by the mainstream psychology. Black, feminist, gay etc. psychologies are examples for this type. They aim for 'empowerment and liberation' of these groups. The ideology-based approaches criticize the underlying ideology of the mainstream psychology. For this type, Holzman (2013) lists Marxist psychology, post-colonial psychology and liberation psychology which are anticapitalist in their understanding of the society. These are "centered on how psychology supports the status quo by socializing its citizens to a capitalist ideology" [40]. Homo psychologicus is a social and ahistorical without any connection with socio-political context much like homo economicus. However, Holzman (2013) is in the opinion that only a few of these critiques refer to Marx and Marxism such as Ian Parker and Klaus Holzkamp. Finally, the third type, epistemology-based criticisms question the methodology of the mainstream psychology and offer alternative ones. This approach views the epistemic foundations of psychology as outdated, dating back to 20th century scientific position that has studied human beings as any other entity in the universe. Another strand under this type criticizes the individualistic isolationism of the mainstream psychology. We can also add under this category the approaches that question universal applicability, reliability and validity of Western-origined psychological knowledge. In addition to these, Holzman (2013) discusses philosophical criticisms of the mainstream psychology such as conceptual confusions in the theoretical foundations of psychology.

While critical psychology appears to be a springboard and an ally for Marxist psychology, some strands of critical psychology are not necessarily anti-capitalist. Parker (2009) warns us of marketized and commercial character of some strands of critical psychology that are mobilized to save the psychology from its crisis under capitalism [41]. From another perspective, some components of Marxist psychology can readily be incorporated into the mainstream psychology, as a result of the mainstream's insistence on wider coverage of human behavior, e.g. system justification theory. This theory can't be considered as completely critical anymore, as its criticisms are now part of social and political psychology curricula worldwide. However, it was inspired by the Marxist ideas of false consciousness and ideology. Ditto for research on authoritarian personality.

Gezgin (2013), in the wake of Gezi Park protests in Turkey discussed how psychology and political resistance such as Gezi resistance could be connected with the field of psychology [14]. Methodologically speaking, an analytical approach was undertaken discussing resistance and psychology by reference to how subfields of psychology would be relevant for political resistance. Endorsing a similar understanding, it is proposed in this article that Marxism and psychology could be better explored through delineation and critical analysis of the subfields of psychology. Thus, in the next sections, some of the outstanding subfields of psychology are discussed with regard to Marxism.

\section{Marxism and Social and Political Psychology}

Mather (2003) reviews Althusserian hegemony to build a Marxist psychology. Although his attempts move towards theoretical waters, there are some other more empirically oriented tracks that are waiting to be explored. For example, Gramscian notion of government by consent is not applicable for all citizens. In fact individual differences among citizens are visible, as some of them are easily and quickly convinced by the government, while some others harbor various shades of 


\section{Psychology \& Psychological Research International Journal}

suspicions against the government. This may very well be a research topic for Marxist-oriented political and social psychologists [42].

Marxian (if not Marxist) influences are visible in system justification theory in social and political psychology which is based on the Marxist notion of false consciousness. Jost (1995), one of the pioneers of this research field defines false consciousness as "the holding of false beliefs that are contrary to one's social interest and which thereby contribute to the disadvantaged position of the self or the group" (p.397, p.400) [43]. Jost (1995) mentions 6 types of false consciousness which is highly promising for extending Marxist theory into empirical world of the field of psychology: (1) Failure to perceive injustice and disadvantage, (2) Fatalism, (3) Justification of social roles, (4) False attribution of blame, (5) Identification with the oppressor, and (6) Resistance to change" (p.397) Likewise, belief in a just world (a.k.a. the just world hypothesis) is inspired by Marxist notions of false consciousness and ideology. When oppressed people join resistance movements and engage in activities, these false beliefs disappear. Fatalistic pessimism and outgroup favoritism favoring the rich and oppressors are other factors to consider. Furthermore, even if the oppressed people have the 'right' consciousness, they may feel desperate about revolting which matches the sixth point above. Then, the notion of political efficacy which can be roughly defined as one's belief in one's power to change something politically would be quite relevant for a Marxist psychology [44].

Interestingly, Jost (1995) thought that "[b]ecause the concept of false consciousness is likely to arouse suspicion because of its Marxian origins, several theoretical and methodological objections to the scientific study of false consciousness are raised and addressed" (p.397) [43]. This sense of suspicion is long gone with regards to system justification research. This research area is now one of the most widespread in political psychology which is a great contribution from Marxism to (political and social) psychology.

Jost (1995) points out that most if not all of contributions of Marxism to psychology is negative. They are mostly based on criticism of the mainstream psychology. In that sense, Jost (1995)'s empirical work on false consciousness can be considered as a positive contribution of Marxism for psychology. Let us also take note of the distinction between Marxist and Marxian, as Jost capitalizes on the notion of 'false consciousness' from a Marxian perspective rather than a Marxist one. While
Marxists are the adherents of the ideology, Marxians are non-Marxists getting inspiration from a set of Marxist concepts [43].

False consciousness is the answer for the questions of why oppressed people don't rebel and revolt or commit suicide. In that sense, Guido (2015) asks the right question [13]: "If, as according to Marxist thought, the objective conditions were given for the socialist revolution, then there was no choice but to ponder, and debate, what it was that impeded historical subjects - leaders and masses from achieving the expected results" (p.47).

As American Marxist historian Howard Zinn stated: "Civil disobedience is not our problem. Our problem is civil obedience. Our problem is that people all over the world have obeyed the dictates of leaders... and millions have been killed because of thisobedience...Our problem is that people are obedient all over the world in the face of poverty andstarvation and stupidity, and war, and cruelty. Our problem is that people are obedient while the jails are full of petty thieves... (and) the grand thieves are running the country. That's our problem" [45].

\section{Marxism, Cognitive Science and Evolutionary Psychology}

According to Marx, material conditions determine consciousness, not vice versa [42]. However, the direction of the relationship does not trivialize consciousness and this stated determinism can take place in various ways. For example, similar conditions of oppression turns a worker to become either a socialist by correctly identifying the unfairness of the system or a Neo-Nazi by blaming immigrants and Jews for social problems. That means same material conditions lead to different consequences over human consciousness. Here enters the notion of Marxist understanding of false consciousness again and again. The individuals may think that they are conscious while that is not the case in reality. Where cognitive science studies the nature of consciousness, the references are usually towards individual mental states, while a Marxist psychology needs to check not only mental processes but also social conditions to confirm whether an individually is really conscious or not. Of course, Marxism and cognitive science are not investigating the same 'consciousness' as the term undertakes various different meanings. However, a Marxist-oriented cognitive scientist and a cognitiveoriented Marxist would have the potential to come up with a newer understanding of consciousness. 


\section{Psychology \& Psychological Research International Journal}

Converging with these views, Brenner (1997) states that "(...) we know that in capitalist society the great mass of the population do not act in accordance with their objective economic interests but very much against them. This is explained by the fact that the dominant ideology of any class society is the ideology of the ruling class and that therefore the oppressed share (to one degree or another) the same outlook as their oppressors. But this is a remarkable fact which calls for further explanation. Historical materialism assumes - since it has no other way of understanding psychological motivation - that people behave rationally, i.e. according to their economic selfinterest (though it is often far from self-evident what that self-interest is). But clearly the behavior of the oppressed is in some significant degree irrational or else they would not continue to put up with their oppression. Here a materialist psychology is indispensable because emotion is the crucial factor at work in this aspect of social life - as it is in many others - and only a psychology can disclose to us how class ideology shapes the feelings of the masses" [21].

As to Marxism and evolutionary psychology, although evolutionary psychology may be promising for a Marxist psychology, the mainstream evolutionary psychology is mostly based on individualistic assumptions which go hand in hand with the neo-liberal doctrine [46]. These mainstream ideas even view social bonding on the basis of genes and attribute genes an agency role. These approaches how hard time when it comes to explaining social bonding not based on genetic relatedness such as comradeship, friendship, god parenting etc. [47]. A revamping of evolutionary psychology questioning its ideological assumptions is necessary.

\section{Marxism and Industrial and Organizational Psychology}

When it comes to industrial psychology, Marxism is quite handy. Mainstream industrial psychology would assume that conflicts are minor in industrial relations, whereas a Marxist industrial psychology would question mainstream approaches which behave as if employers and employees on the one hand, and managers and subordinates on the other may form a team, can be studied as if there is no social divisions and as if both employers and employees can be motivated equally and in the same way. Obviously, why an employer works (if he does) and why an employee works might be quite different. An employer can work for self-actualization needs while employees may just do the job for survival, referring to Maslowian model of motivation. A cartoon notes a conversation between a boss and a worker:
Worker: What a beautiful car you have boss.

Boss: If you would work harder this year, if you would set higher targets for yourself, I will have even a more beautiful one.

This dialogue again shows that the motivations can't be treated as if they are same. Another motivational difference can be observed in 'Mandira Filozofu Istanbul' (Dairy Philosopher Istanbul, 2015, directed by Müfit Can Saçıntı), one of the best anti-capitalist movies in Turkish history of art, where the bosses set higher targets to grow while the middle managers and subordinates struggle hard to meet the unrealistic targets and otherwise they are fired. If they would surpass a target on that year, the management 'rewards' them by setting even higher targets.

A blatantly psychological conceptualization in Marxist toolbox is, in fact, alienation, as stated before. The key point in Marxist understanding of alienation is the loss of meaning in work. The notion of alienation assumes that the characterizing property of human beings as a species is labor and people in general love to work if it is meaningful for them. However, under capitalism they are no longer producing a product as a whole which fails to add meaning to their work activities; they are just producing components of a whole. The second meaning of alienation refers to going far away from the human nature. But this notion of 'human nature' is a moot issue. This is another point to be discussed by Marxist psychologists.

\section{Marxism and Educational and Developmental Psychology}

Vygotsky and Freire would be the key figures to review to build a Marxist educational and developmental psychology [48]. How younger generations are indoctrinated with false consciousness and system justification would be a major research topic for a Marxist educational and developmental psychology [49]. Rahmani (1973) presents a study which showed that the top job preferred by 8th-grade Soviet students was being a worker [28]. Moving from this finding, textbooks and various components of hidden curriculum can be analyzed to identify class representations and imaginations of class society. For example, a school principal stating "you are all bright students. You all will be rich when you will grow up. You won't wear dirty clothes and you won't let poor people to wear your shiny clothes" is an example for a hidden curriculum element openly exhibiting class discrimination and setting and normalizing class inequality. 


\section{Psychology \& Psychological Research International Journal}

Moral development can be another area to be contributed by a Marxist psychology. For one thing, moral dilemmas utilized in moral development research can be interpreted from a class perspective to come up with a more class-conscious understanding of morality. Moral development has implications not only for human development fields, but also for educational psychology, political psychology and organizational and industrial psychology [50].

\section{Marxism, Personality and Clinical Psychology}

Is capitalism with its stressful jobs, unemployment, consumer society, financial pressure etc. transforming human personality? Youngsters usually represent the rebels or it used to be the case. Work life expects obedience. What are the processes behind this capitalist transformation of human personality? If we are still hopeful, how to reverse or undo the damages of capitalism over human personality? Richard Sennett's

masterpiece 'The Corrosion of Character: The Personal Consequences of Work in the New Capitalism' could be quite useful to answer these questions [51]. Fred Newman's social therapy approach which is based on philosophy and Marxism and which does not share the individualistic assumptions of the mainstream psychology can be noted here. As a radical way to help people with emotional pain, social therapy prefers group work over one-to-one therapy, as the former offers opportunities to break individualistic isolationism of the individuals under capitalism [40].

\section{Marxism and Economic and Consumer Psychology}

Pavón-Cuéllar (2015) discusses the psychology of the capitalists as a new avenue for a Marxist psychology. Marx, as shown by Pavón-Cuéllar (2015) described the psychology of capitalists in his works [52]. This discussion has implications for the subfield of economic psychology which covers among its many other subjects, the mental states of the investors (investor psychology) and organizational psychology which has developed a new research area under the notion of managerial and organizational cognition. Furthermore, consumer society is a promising topic for Marxist economic psychologists.

\section{Future Research Directions for Marxist Psychology}

To build up a Marxist industrial psychology, a scale on motivation and alienation can be developed that would allow empirical research. An industrial psychology from the perspective of the employee is vital for a more realistic understanding of the industrial relations.

For a Marxist political and social psychology, more research can be conducted about system justification, false consciousness, hegemony, government by consent, authoritarian personality, social dominance orientation etc. [53].

Other than the subfields of psychology discussed with regard to Marxism so far, media psychology and crosscultural psychology would be appropriate for a Marxist reconfiguration of the mainstream psychology: How the state and the capitalists reframe social problems to build and reproduce false consciousness and low political efficacy? This will be the major question to concentrate on for Marxist media psychology. Elements and tools of mainstream media that spread and bolster false consciousness through reframing or ignorance can be forged into a scale for empirical research. A Marxist crosscultural psychology would consider class similarities across cultures that are mostly treated as homogenous entities by the mainstream cross-cultural psychology in comparison and contrasting of various cultures. Furthermore, Marxism could make theoretical contributions to the field, by discussing and elaborating on whose class cultures are represented in the notions of 'national culture', 'ethnic culture', 'regional culture' and 'local culture'.

Theoretically speaking, other neighboring fields to consider for Marxist psychology would be radical psychology, emancipatory/ liberation psychology, activist psychology, critical psychology, vernacular psychology, indigenous psychology, post-colonial psychology (cf. Hook, 2005) and feminist psychology. Marxist psychology, after extension and elaboration, can be a theoretical umbrella covering some of the components of these approaches [54,55].

\section{Conclusion}

In this article, the notion of Marxist psychology was presented and discussed which was followed by an attempt to link Marxism with various subfields of psychology such as social and political psychology, industrial psychology, cognitive science and evolutionary psychology among others. The author hopes that the suggestions in this article would help Marxists, psychologists and researchers in their endeavor to make mainstream psychology more meaningful and relevant for 


\section{Psychology \& Psychological Research International Journal}

the masses and the people through their theoretical as well as empirical works.

\section{References}

1. Gezgin UB (2012) Marksizm ve psikanaliz: Hangi Marksizm, Hangi psikanaliz? [Marxism and psychoanalysis: Which Marxism, which psychoanalysis?] Düşünbil 30: 25-30.

2. Gezgin UB (2005) Yansıbilimci (psikolog) gözüyle şiddet ve saldırganlık [Violence and aggresion from the perspective of a psychologist]. İzinsiz Gösteri.

3. Elhammoumi M (2012) Marxist psychology: a research paradigm whose time has come. Estudos de Psicologia 29(1): 3-11.

4. Elhammoumi M (2002) To create psychology's own capital. Journal for the Theory of Social Behavior 32(1): 89-104.

5. Rubinštejn SL, Blakeley TJ (1987) Problems of psychology in the works of Karl Marx. Studies in Soviet Thought 33(2): 111-130.

6. Hayes G (2015) The spectre of communism is not haunting psychology. Annual Review of Critical Psychology 12: 20-26.

7. Hayes G (2001) Marxism and psychology: A vignette. PINS (Psychology in Society) 27: 46-52.

8. Jovanović G (2011) Knowledge and interest in psychology: From ideology to ideology critique and beyond. Annual Review of Critical Psychology 9: 1019.

9. Larocco S (2011) Ideology beyond Marx: Shame, disambiguation, and the social fashioning of reparation. Annual Review of Critical Psychology 9: 84-91.

10. Teo $\mathrm{T}$ (2011) Reconstructing the critique of ideology: A critical-hermeneutic and psychological outline. Annual Review of Critical Psychology 9: 20-27.

11. Parker I (2011) Introduction. Annual Review of Critical Psychology 9: 8-9.

12. Sica AM (1980) Man in Marxist theory and the psychology of personality by Lucien Seve and John McGreal. American Journal of Sociology 85(4): 971973.
13. Guido RH (2015) The Freudo-Marxist mission. Annual Review of Critical Psychology 12: 45-52.

14. Gezgin UB (2013) Gezi Direnişi sonrası ezilenlerin psikolojisi.

15. Gezgin UB (2002) Economic crisis as trauma and psychotherapy as the guardian of status quo. Lecture delivered The XVIth European Psychology Students Conference, Avanos, Turkey.

16. Thobaben RG (1977) Toward a Marxist Psychology by Philip M. Brown. The Antioch Review 35(2/3): 311.

17. Painter D (2012) Speaking in tongues: A report on the second marxism and psychology conference, Morelia, Mexico, 9-11 August 2012. PINS (Psychology in Society) 43: 72-75.

18. Thielen M (1986) Psychology in Utopia. Toward a Social History of Soviet Psychology by Alex Kozulin. Soviet Studies 38(1): 114-116.

19. Trevarthen C (1991) Developmental psychology in the Soviet Union by Jaan Valsiner. Soviet Studies, 43(1): 183-187.

20. Decker HS (1999) Freud and the Bolsheviks: Psychoanalysis in Imperial Russia and the Soviet Union by Martin A. Miller. The American Historical Review 104(5): 1794-1795.

21. Brenner F (1997) Psychoanalysis and the "empty place" of psychology within Marxism.

22. Gezgin UB (2000) A half century of soviet psychology: A comparison of the two schools in terms of Wertheimer's axes. [unpublished manuscript]

23. Joravsky D (1977) The Mechanical spirit: The Stalinist marriage of Pavlov to Marx. Theory and Society 4(4): 457-477.

24. Rey FLG (2014) Advancing further the history of Soviet psychology: Moving forward from dominant representations in Western and Soviet psychology. History of Psychology 17(1): 60-78.

25. Smith M (1985) Psychology and Psychiatry Today: A Marxist view. By Joseph Nahem. Philosophy of the Social Sciences 15(2): 216-221.

26. González-Rey F (2015) Marxism, subjectivity and cultural historical psychology: Moving forward on an 


\section{Psychology \& Psychological Research International Journal}

unfinished legacy. Annual Review of Critical Psychology 12: 27-35.

27. Payne TR (1967) The 'brain-psyche' problem in Soviet Psychology: A survey of its development and perspectives. Studies in Soviet Thought: Trends and Perspectives in Current Soviet and East-European Philosophy 7(2): 83-100.

28. Rahmani L (1973) Social psychology in the Soviet Union. Studies in Soviet Thought 13(3/4): 218-250.

29. Veresov N (2005) Marxist and non-Marxist aspects of the cultural-historical psychology of L.S. Vygotsky. Outlines 7(1): 31-49.

30. Packer MJ (2008) Is Vygotsky relevant? Vygotsky's Marxist psychology. Mind, Culture, and Activity, 15(1): 8-31.

31. Rey FLG (2011) A re-examination of defining moments in Vygotsky's work and their implications for his continuing legacy. Mind, Culture, and Activity 18: $257-275$.

32. Dafermos (2014) Vygotsky's analysis of the crisis in psychology: Diagnosis, treatment, and relevance. Theory \& Psychology 24(2): 147-165.

33. Edwards \& Daniels (2004) Editorial. Educational Review 56(2): 107-111.

34. Wendeng Yang, Haosheng Ye (2014) Theoretical psychology in China: Past, present, and future. Theory \& Psychology 24(6): 813-829.

35. Wendeng Yang, Haosheng Ye (2013) Methodological implications of Marxist practical philosophy for psychology: A perspective from China. Theory \& Psychology 23(3): 371-390.

36. Jing Q, Pan Shu (2000) Encyclopedia of Psychology. In AE Kazdin (Edn.). New York: Oxford University Press 6: 32-33.

37. Teo T (1999) Marxist psychologists: Bald intellectuals, officials of truth or revolutionaries. Theory \& Psychology 9(3): 427-432.

38. Barnes, Milovanovic (2015) Class, resistance, and the psychologization of development in South Africa. Theory \& Psychology 25(2): 222-238.
39. Prilleltensky I (1990) The politics of abnormal psychology: Past, present, and future. Political Psychology 11(4): 767-785.

40. Holzman L (2013) Critical psychology, philosophy, and social therapy. Human Studies 36(4): 471-489.

41. Parker I (2009) Critical psychology and revolutionary Marxism. Theory \& Psychology 19(1): 71-92.

42. Mather R (2003) Hegemony and Marxist psychology. Theory \& Psychology 13(4): 469-487.

43. Jost JT (1995) Negative illusions: Conceptual clarification and psychological evidence concerning false consciousness. Political Psychology 16(2): 397424.

44. Gezgin UB (2014a) 1 Mayıs 2014 and Solun Psychological Capital.

45. Zinn H (2011) Howard zinn in his own words.

46. McKinnon S (2005) Neo-Liberal Genetics: The Myths and Moral Tales of Evolutionary Psychology. Chicago: Prickly Paradigm Press.

47. Gezgin UB (2017b) Evrimsel psikolojinin mitleri: Eleștirel olmayan bir evrimciliğin sefaleti [The Myths of Evolutionary Psychology: The Poverty of A NonCritical Evolutionism]. Yeni E 8: 27-32.

48. Collins C (2011) Reflections on CHAT and Freire's participatory action research from the West of Scotland: Praxis, politics, and the "Struggle For Meaningful Life". Mind, Culture, and Activity 18(2): 98-114.

49. Rauter EA (1971/1999) Düzene Uygun Kafalar Nasıl Oluşturulur [Wie eine Meinung in einem Kopf entsteht. Uber das Herstellen von Untertanen]. Istanbul: Bakış Kitaplığı.

50. Gezgin UB (2017a) Ahlaksal Gelişim: Psikolojik Bulgular ve Tartışmalar [Moral Development: Psychological Findings and Discussions]. Alternatif Eğitim Dergisi 2(5): 131-150.

51. Sennett R (1998) The Corrosion of Character: The Personal Consequences of Work in the New Capitalism. New York: W. W. Norton.

52. Pavón-Cuéllar (2015) The metapsychology of capital. Annual Review of Critical Psychology 12: 53-58. 
53. Gezgin UB (2014b) Omnipresent and omnipotent authoritarianism: Authoritarian media vs. social media? [Hazır Ve Nazır Ve Kadir-i Mutlak Yetkecilik: Yetkeci Medya vs. Sosyal Medya?] Alternative Politics 6(1): 32-61.

54. Hook (2005) A critical psychology of the postcolonial 15(4): 475-503.
55. Gezgin UB (2015) İnsan Hakları, Demokratik Okul ve Anadilinde Öğretim için Çokkültürlü Eğitim [Multicultural Education for Human Rights, Democratic School and Instruction in the Mother Tongue]. Ankara: Ütopya.

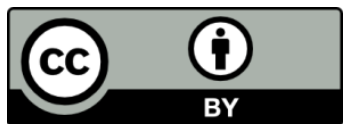

